\title{
Remarkable influence of reductant structure on the activity of alumina-supported silver catalyst for the selective catalytic reduction of NOx
}

\author{
Yunbo Yu, Xiaoping Song, Hong He* \\ State Key Laboratory of Environmental Chemistry and Ecotoxicology, Research Center for Eco-Environmental Sciences, Chinese Academy of Sciences, 18 Shuangqing Road, \\ Haidian District, Beijing 100085, China
}

\section{A R T I C L E I N F O}

\section{Article history:}

Received 3 December 2009

Revised 27 January 2010

Accepted 14 February 2010

Available online 29 March 2010

\section{Keywords:}

Selective catalytic reduction

Alcohol isomer

Enolic species

$\alpha-\mathrm{H}$

Alumina-supported silver catalyst

\begin{abstract}
A B S T R A C T
This study investigated the selective catalytic reduction of NOx over alumina-supported silver catalyst by butyl alcohol isomers. Butyl alcohol (BA), sec-butyl alcohol (SBA), and isobutyl alcohol (IBA) showed similarly high efficiency for NOx reduction at low temperatures, while tert-butyl alcohol (TBA) exhibited a much lower performance. In situ diffuse reflectance infrared Fourier transform spectroscopy was used to clarify the remarkable influence of the alcohol structure on NOx reduction. A high surface concentration of enolic species was observed during the partial oxidation of BA, IBA, and SBA, leading to a high concentration of isocyanate species and high NOx conversion. However, due to the absence of $\alpha-\mathrm{H}$, it was difficult to partially oxidize TBA to form the enolic species, which resulted in its low efficiency for NOx reduction. Based on the results obtained, a mechanism was proposed to explain the close relationship between the structure feature of alcohols and NOx reduction efficiency.
\end{abstract}

(ㄷ) 2010 Elsevier Inc. All rights reserved.

\section{Introduction}

The selective catalytic reduction of NOx by hydrocarbons (HC$\mathrm{SCR}$ ) has received much attention as a potential method for removing NOx emissions from various oxygen-rich exhausts of diesel engines, lean-burn gasoline engines, and gas engines [1,2]. A number of catalysts have hitherto been found to be effective for NOx reduction in the presence of excess oxygen, of which alumina-supported silver catalyst $\left(\mathrm{Ag} / \mathrm{Al}_{2} \mathrm{O}_{3}\right)$ is one of the most effective for the HCSCR of NOx [3-12]. When using oxygenated hydrocarbons, particularly ethanol as a reductant, $\mathrm{Ag} / \mathrm{Al}_{2} \mathrm{O}_{3}$ shows high activity even in the presence of $\mathrm{SO}_{2}$ and $\mathrm{H}_{2} \mathrm{O}$ [3]. To improve the overall performance of $\mathrm{Ag} / \mathrm{Al}_{2} \mathrm{O}_{3}$ for NOx reduction, much effort has been devoted to gaining insight into the reaction mechanism. Generally, the SCR of NOx by ethanol can be considered as follows: $\mathrm{NO}+\mathrm{O}_{2}+\mathrm{C}_{2} \mathrm{H}_{5} \mathrm{OH} \rightarrow \mathrm{NOx}$ (adsorbed nitrate in particular) + ad$\mathrm{C}_{x} \mathrm{H}_{y} \mathrm{O}_{z} \rightarrow \mathrm{R}-\mathrm{ONO}+\mathrm{R}-\mathrm{NO}_{2} \rightarrow-\mathrm{NCO}+-\mathrm{CN} \rightarrow \mathrm{N}_{2} \quad[5,6,10-15]$. Nevertheless, many questions remain regarding the details of this multi-step process. It has been proposed that acetate derived from the partial oxidation of ethanol plays a crucial role in the formation of isocyanate species (-NCO), as well as in the global NOx reduction process $[9,10,12,14]$. From our recent research, large amounts of surface enolic species were observed by in situ diffuse reflectance infrared Fourier transform spectroscopy (DRIFTS) during both the partial oxidation of ethanol and the NOx reduction with

\footnotetext{
* Corresponding author. Fax: +86 1062849123.

E-mail address: honghe@rcees.ac.cn (H. He).
}

ethanol over $\mathrm{Ag} / \mathrm{Al}_{2} \mathrm{O}_{3}$. The surface enolic species exhibited much higher activity in reaction with nitrate and/or $\mathrm{NO}+\mathrm{O}_{2}$ to form -NCO species than that of acetate, demonstrating its crucial role in the SCR of NOx by ethanol [16-20]. Previous research has identified that the enolic species also plays a key role in NOx reduction by other alcohols (isopropyl alcohol, 1-propanol, 1-butanol) over $\mathrm{Ag} / \mathrm{Al}_{2} \mathrm{O}_{3}$ [20-22], acetaldehyde over $\mathrm{Ag} / \mathrm{Al}_{2} \mathrm{O}_{3}$ [16] and $\mathrm{Co} / \mathrm{Al}_{2} \mathrm{O}_{3}$ [23], and acetylene over ZSM-5 [24]. Interestingly, substantial quantities of enols in the gas phase have been observed by photoionization mass spectrometry during hydrocarbon combustion [25] and catalytic oxidation [26]. The above results strongly suggest that adsorbed enolic species and/or enols in the gas phase are common intermediates involved in the partial oxidation chemistry of hydrocarbons and oxygenated hydrocarbons. During NOx reduction by ethanol over $\mathrm{Ag} / \mathrm{Al}_{2} \mathrm{O}_{3}$, it has been proposed that ethanol principally reacts with oxygen to form acetaldehyde, which is followed by isomerization to ethenol. Additionally, an enolic anion $\left(\mathrm{CH}_{2}=\mathrm{CH}-\mathrm{O}^{-}\right)-\mathrm{M}^{+}$is formed by hydrogen extraction when ethenol is adsorbed on the surface of $\mathrm{Ag} / \mathrm{Al}_{2} \mathrm{O}_{3}$. Meanwhile, the possible occurrence of aldol condensation of acetaldehyde may lead to the formation of C4 enolic species as shown in Scheme 1 [18].

Obviously, if the formation of surface enolic species follows the hypothesis as described above, two prerequisites must be met. Firstly, the selected reductant must contain at least one $\mathrm{C}-\mathrm{C}$ bond. This has been clarified by our previous research, in which the enolic species was rarely observed when $\mathrm{CH}_{3} \mathrm{OH}$ and $\mathrm{CH}_{3} \mathrm{OCH}_{3}$ were partially oxidized over $\mathrm{Ag} / \mathrm{Al}_{2} \mathrm{O}_{3}[21,22]$. Secondly, it is widely accepted that the structure feature of $\mathrm{H}-\mathrm{C}-\mathrm{O}-\mathrm{H}$ is required for 


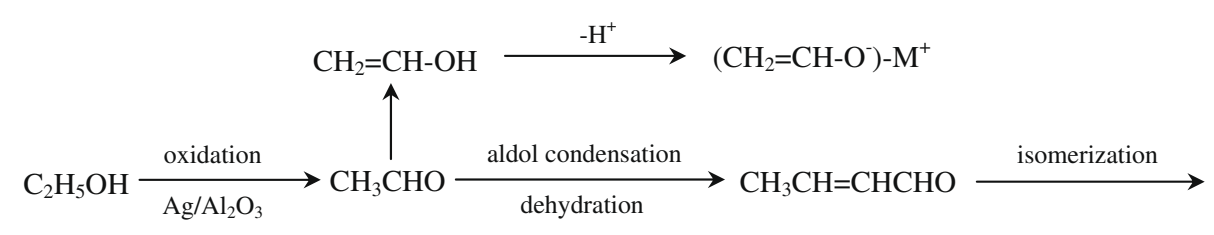<smiles>C=CC=COC1CC[M]OC1</smiles>

\section{$\mathrm{M}=\mathrm{Al}, \mathrm{Ag}$}

Scheme 1. The hypothesis for the surface enolic species formation during the partial oxidation of ethanol on $\mathrm{Ag} / \mathrm{Al}_{2} \mathrm{O}_{3}$.

the partial oxidation of alcohols to aldehydes and/or ketones. That is, the $\mathrm{OH}$ group must be attached to a carbon atom that is bonded to at least one hydrogen atom (denoted as $\alpha-\mathrm{H}$ ). Considering that enols are the tautomers of aldehyde/ketones, the presence of $\alpha-\mathrm{H}$ is also a prerequisite for the formation of enolic species during partial oxidation of alcohols over $\mathrm{Ag} / \mathrm{Al}_{2} \mathrm{O}_{3}$. To highlight this issue in the present study, butyl alcohol isomers with and without $\alpha-\mathrm{H}$ were employed as reductants for the NOx reduction over $\mathrm{Ag}$ / $\mathrm{Al}_{2} \mathrm{O}_{3}$. Through the combination of the DRIFTS results and the activity measurements, the crucial role of surface enolic species in the SCR of NOx by alcohols was further identified, which also provides an intrinsic criterion for the selection of reductants with high efficiency for NOx removal.

\section{Experimental}

\subsection{Catalyst preparation}

The 4 wt.\% $\mathrm{Ag} / \mathrm{Al}_{2} \mathrm{O}_{3}$ catalyst was prepared by impregnation of pseudoboehmite powder (AlOOH, $292 \mathrm{~m}^{2} \mathrm{~g}^{-1}$ ) with an appropriate amount of silver nitrate aqueous solution and was then evaporated to dryness in a rotary evaporator at $333 \mathrm{~K}$ under reduced pressure. The resulting paste was dried at $393 \mathrm{~K}$ overnight and then calcined in air at $873 \mathrm{~K}$ for three hrs. Before the catalytic activity test, the catalyst was sieved through 20-40 meshes.

\subsection{Catalytic activity test}

The catalytic activity was measured with a fixed-bed quartz flow reactor (inner diameter $10 \mathrm{~mm}$ ) by passing a mixture of $800 \mathrm{ppm} \mathrm{NO}, 783 \mathrm{ppm}$ butyl alcohol isomers (BA, IBA, SBA or TBA), 10 vol. $\% \mathrm{H}_{2} \mathrm{O}$, and 10 vol. $\% \mathrm{O}_{2}$ in $\mathrm{N}_{2}$ at a rate of $2000 \mathrm{ml} \mathrm{min}^{-1}$ over $0.6 \mathrm{~g}$ catalyst $\left(W / F=0.018 \mathrm{~g} \mathrm{~s} \mathrm{ml}, \mathrm{GHSV}=\sim 50,000 \mathrm{~h}^{-1}\right)$. An aqueous solution of $\mathrm{C} 4$ alcohol was supplied with a syringe pump into the gas stream and vaporized by a coiled heater at the inlet of the reactor. NOx conversion was analyzed online by a chemiluminescence $\mathrm{NO} / \mathrm{NO}_{2} / \mathrm{NOx}$ analyzer (42C-HL, Thermo Environmental). Analysis of the concentrations of by-products such as $\mathrm{N}_{2} \mathrm{O}, \mathrm{NH}_{3}$, and organo-nitrogen compounds $\left(\mathrm{R}-\mathrm{ONO}, \mathrm{R}-\mathrm{NO}_{2}\right)$ was carried out using an online Nicolet 380-FT-IR spectrophotometer (Thermo Nicolet) equipped with a gas cell of volume $0.2 \mathrm{dm}^{3}$. In this case, the gas cell of 380-FT-IR spectrophotometer and gas line after the reactor were heated to $120^{\circ} \mathrm{C}$ to avoid water condensation.

\subsection{In situ DRIFTS studies}

In situ DRIFTS spectra were recorded on a Nexus 670 FT-IR spectrophotometer (Thermo Nicolet), equipped with an in situ diffuse reflection chamber and a high-sensitivity MCT detector cooled by liquid nitrogen. The $\mathrm{Ag} / \mathrm{Al}_{2} \mathrm{O}_{3}$ catalyst used in the in situ DRIFTS studies was finely ground and placed into a ceramic crucible in the in situ chamber. Mass flow controllers and a sample temperature controller were used to simulate the real reaction conditions. Prior to recording each DRIFTS spectrum, the $\mathrm{Ag} / \mathrm{Al}_{2} \mathrm{O}_{3}$ catalyst was heated in situ in a flow of $\mathrm{O}_{2}+\mathrm{N}_{2}$ for $60 \mathrm{~min}$ at $873 \mathrm{~K}$, then cooled to the desired temperatures for taking the reference spectrum. Water vapor was introduced into the gas stream by means of a syringe pump and carried into the in situ DRIFTS chamber. Water vapor in the gas phase and adsorbed water molecules on the surface of $\mathrm{Ag} / \mathrm{Al}_{2} \mathrm{O}_{3}$ show strong infrared adsorption, so a reference spectrum of $\mathrm{Ag} / \mathrm{Al}_{2} \mathrm{O}_{3}$ in a flow of $\mathrm{O}_{2}+\mathrm{N}_{2}$ (and water vapor, where appropriate) was subtracted from each spectrum at the respective temperature. All gas mixtures were fed at a flow of $300 \mathrm{ml} \mathrm{min}^{-1}$. All spectra reported here were taken at a resolution of $4 \mathrm{~cm}^{-1}$ for 32 scans.

\section{Results}

3.1. Catalytic activity of $\mathrm{Ag} / \mathrm{Al}_{2} \mathrm{O}_{3}$ for NOx reduction by butyl alcohol isomers

The results obtained for the catalytic activities of $\mathrm{Ag} / \mathrm{Al}_{2} \mathrm{O}_{3}$ for the SCR of NOx by butyl alcohol isomers are shown in Fig. 1. When using TBA as a reductant, NOx conversion was below $23 \%$, even at temperatures of up to $673 \mathrm{~K}$. After this, however, the NOx conversion increased rapidly as temperatures increased and reached a

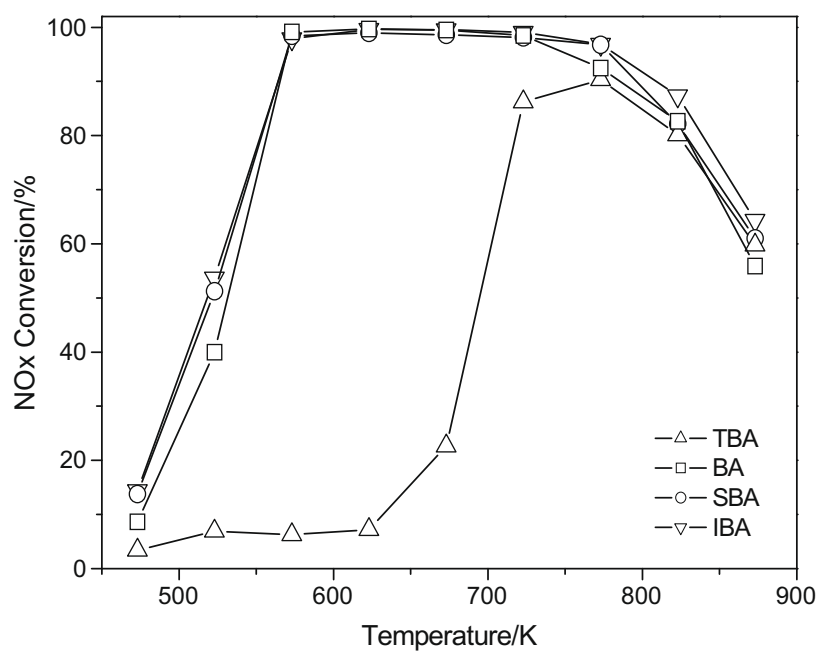

Fig. 1. Activities of $4 \mathrm{wt} . \% \mathrm{Ag} / \mathrm{Al}_{2} \mathrm{O}_{3}$ for the $\mathrm{SCR}$ of $\mathrm{NOx}$ with various reductants. Reaction conditions: NO 800 ppm, TBA, BA, SBA or IBA 783 ppm, $\mathrm{O}_{2} 10$ vol.\%, $\mathrm{H}_{2} \mathrm{O}$ $10 \mathrm{vol} . \%, \mathrm{~N}_{2}$ as balance; total flow $=2000 \mathrm{ml} \mathrm{min}^{-1}, W / F=0.018 \mathrm{~g} \mathrm{~s} \mathrm{ml}$, GHSV $=$ $\sim 50,000 \mathrm{~h}^{-1}$. 
maximum of $90 \%$ at $773 \mathrm{~K}$. As for $\mathrm{BA}$, however, the $\mathrm{Ag} / \mathrm{Al}_{2} \mathrm{O}_{3}$ showed much higher efficiency for NOx reduction, particularly in the low temperature range. The NOx conversion started at $473 \mathrm{~K}$ and rapidly increased to $40 \%$ with a temperature increase to $523 \mathrm{~K}$. The maximum NOx conversion reached $99 \%$ at $673 \mathrm{~K}$, and the average NOx conversion was $90 \%$, even within the wide temperature range of $573-773 \mathrm{~K}$. In the case of NOx reduction by IBA and SBA, very similar NOx conversions were obtained within the temperature range of $473-873 \mathrm{~K}$ compared with that of BA. These results suggest that NOx reduction by BA, IBA, and SBA possibly follows similar reaction pathways, while NOx conversion by TBA may undergo a different reaction mechanism.

During this process, the formation of by-products $\left(\mathrm{N}_{2} \mathrm{O}, \mathrm{NH}_{3}\right.$, and organo-nitrogen compounds) was measured online by a Nicolet 380-FT-IR spectrophotometer. When using TBA as a reductant, the maximum concentration of $\mathrm{N}_{2} \mathrm{O}$ was $3.0 \mathrm{ppm}(823 \mathrm{~K}$ ). As for $\mathrm{BA}, \mathrm{SBA}$, and IBA, the maximum value of $\mathrm{N}_{2} \mathrm{O}$ was $11.1(573 \mathrm{~K})$, $8.1(573 \mathrm{~K})$, and $11.2 \mathrm{ppm}(523 \mathrm{~K})$, respectively. In all cases, only trace amount of organo-nitrogen compounds was observed, suggesting that $\mathrm{Ag} / \mathrm{Al}_{2} \mathrm{O}_{3}$ possesses high selectivity to $\mathrm{N}_{2}$ during the NOx reduction by butyl alcohol isomers.

\subsection{In situ DRIFTS study}

\subsubsection{Steady state in situ DRIFTS study of the partial oxidation of C4} alcohols

Considering that the HC-SCR of NOx starts with the partial oxidation of the reductant, the in situ DRIFTS spectra observed during partial oxidation of butyl alcohol isomers over $\mathrm{Ag} / \mathrm{Al}_{2} \mathrm{O}_{3}$ were first investigated. The in situ DRIFTS of $\mathrm{Ag} / \mathrm{Al}_{2} \mathrm{O}_{3}$ spectra in flowing $\mathrm{TBA}+\mathrm{O}_{2}$ at different temperatures are shown in Fig. 2. At $523 \mathrm{~K}$, the feature peaks of adsorbed TBA over $\mathrm{Ag} / \mathrm{Al}_{2} \mathrm{O}_{3}$ were clearly observed according to the intensive study of Korppi-Tommola [27]. Peaks at 1470,1389 , and $1365 \mathrm{~cm}^{-1}$ were attributed to methyl bending of tert-butyl. Peaks at 1232 and $1205 \mathrm{~cm}^{-1}$ were assigned to skeletal stretching of tert-butyl. The $\mathrm{OH}$ bending frequency was rarely observed, indicating that adsorbed TBA may present as tertbutyl ester. Meanwhile, a small amount of formate was observed at 1593 and $1392 \mathrm{~cm}^{-1}$, which can be assigned to the asymmetric and symmetric stretching vibration modes of carboxyl (COO), respectively $[28,29]$. The further increase of the temperature to $623 \mathrm{~K}$ resulted in the formation of large amounts of formate at the expense of a sharp decrease in the intensities of adsorbed TBA peaks. Within the high temperature range of $673-773 \mathrm{~K}$, strong peaks were observed at 1578 and $1462 \mathrm{~cm}^{-1}$, indicating the formation of a large amount of acetate [30,31]. Based on our previous studies [16-22], the shoulder at $1633 \mathrm{~cm}^{-1}$ can be assigned to the asymmetric stretching vibration mode of $\mathrm{C}=\mathrm{C}-\mathrm{O}^{-}$, as the structure feature of surface enolic species. Our previous research also suggests that for the enolic species, there should be other two peaks at around 1416 and $1336 \mathrm{~cm}^{-1}$, attributed to the symmetric stretching vibration of $\mathrm{C}=\mathrm{C}-\mathrm{O}^{-}$and $\mathrm{C}-\mathrm{H}$ deformation mode, respectively. The absence of the two peaks, however, could be due to the low concentration of the enolic species over $\mathrm{Ag} / \mathrm{Al}_{2} \mathrm{O}_{3}$ during the SCR of NOx by TBA. The appearance of formate and acetate species indicated that chemical bond breakage of TBA and further oxidation occurred.

The same set of experiments was performed after exposing the catalyst to $\mathrm{BA}+\mathrm{O}_{2}$, with the results shown in Fig. $2 \mathrm{~B}$. At $523 \mathrm{~K}$, a
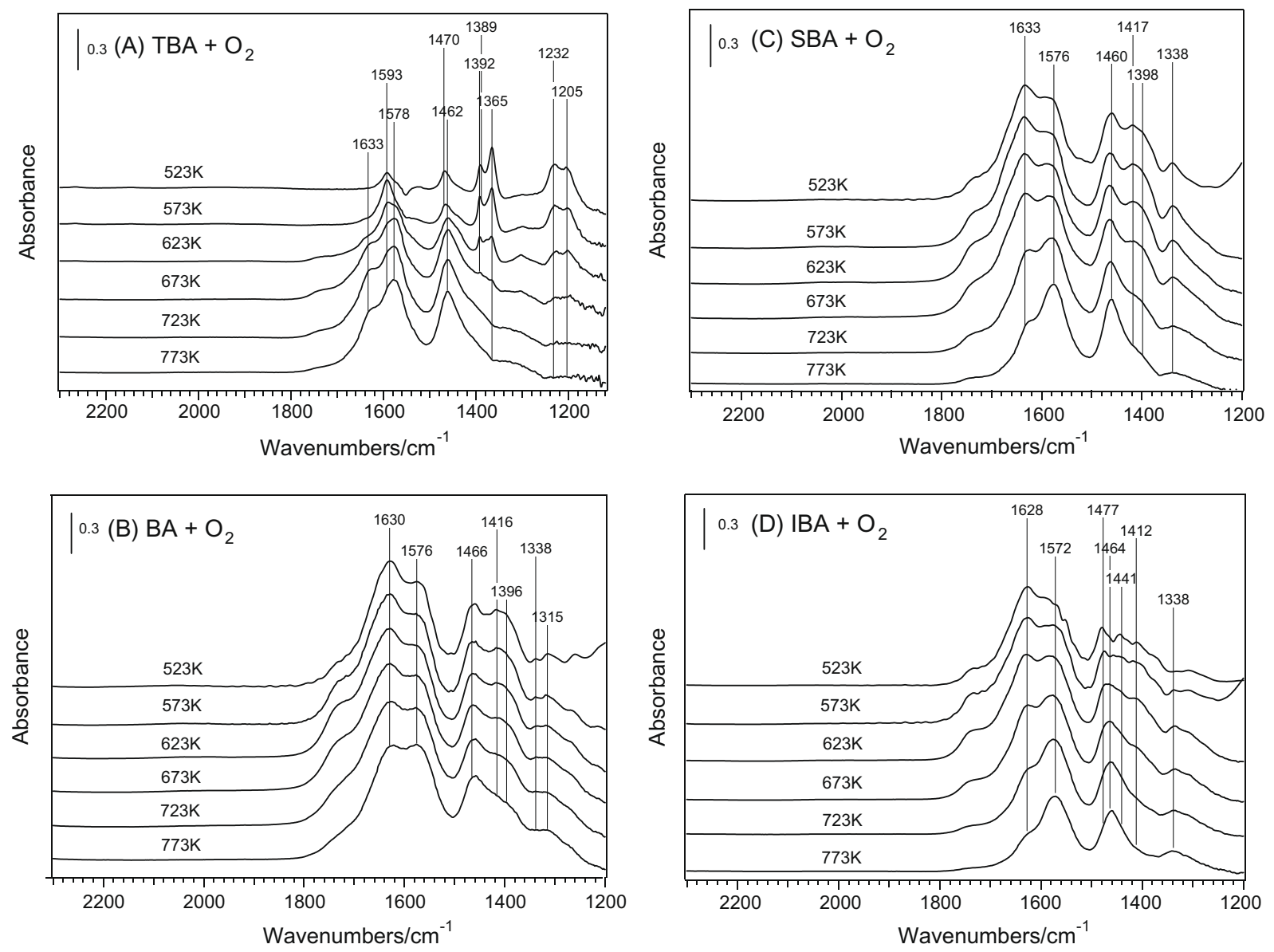

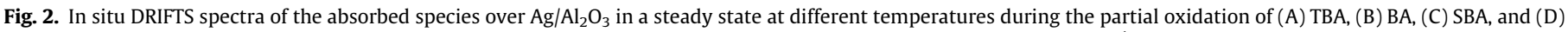
IBA. Reaction conditions: TBA, BA, SBA, or IBA 783 ppm, $\mathrm{O}_{2} 10$ vol.\%, $\mathrm{H}_{2} \mathrm{O} 10$ vol.\%, $\mathrm{N}_{2}$ as balance; total flow $=300 \mathrm{ml} \mathrm{min}^{-1}$. 
strong peak was observed at $1630 \mathrm{~cm}^{-1}$, together with peaks at 1416 and $1338 \mathrm{~cm}^{-1}$, which can be attributed to surface enolic species [16-22]. Meanwhile, surface acetate was observed at 1576 and $1466 \mathrm{~cm}^{-1}$. Increasing the temperature to $573 \mathrm{~K}$ enhanced the formation of enolic species, and within the wide temperature range of $523-723 \mathrm{~K}$, the peak at $1630 \mathrm{~cm}^{-1}$ showed the strongest intensity, indicating that the enolic species was dominant during this process. A further increase in the temperature to $773 \mathrm{~K}$ decreased the intensity of the enolic species and acetate became dominant on the surface of $\mathrm{Ag} / \mathrm{Al}_{2} \mathrm{O}_{3}$.

The in situ DRIFTS spectra of $\mathrm{Ag} / \mathrm{Al}_{2} \mathrm{O}_{3}$ observed during the partial oxidation of SBA are shown in Fig. $2 \mathrm{C}$. The enolic species was observed at 1633,1417 , and $1338 \mathrm{~cm}^{-1}$, and this species was dominant within the temperature range of 523-673 K. Increasing the temperature to 723 and $773 \mathrm{~K}$ enhanced the conversion of enolic species to acetate $\left(1576\right.$ and $1460 \mathrm{~cm}^{-1}$ ). In addition, the observed peak at $1398 \mathrm{~cm}^{-1}$ was attributed to methyl bending. Compared to the partial oxidation of SBA, very similar DRIFTS spectra were obtained when $\mathrm{Ag} / \mathrm{Al}_{2} \mathrm{O}_{3}$ was exposed to IBA in the presence of excess oxygen within the temperature of 523-773 K (Fig. 2D).

\subsubsection{Dynamic study of the reactivity of the surface adsorbed species} over $\mathrm{Ag} / \mathrm{Al}_{2} \mathrm{O}_{3}$

The reactivity of the partial oxidation products of butyl alcohol isomers was further investigated by the transient response of in situ DRIFS method. First, we chose the temperature of $723 \mathrm{~K}$ for TBA and $573 \mathrm{~K}$ for the other three alcohols as the examined temperature at which $\mathrm{Ag} / \mathrm{Al}_{2} \mathrm{O}_{3}$ gave moderate NOx conversions and high concentrations of partial oxidation products. After the catalyst was exposed to $\mathrm{TBA}+\mathrm{O}_{2}$ for $60 \mathrm{~min}$ at $723 \mathrm{~K}$ (Fig. 3A), strong peaks appeared, attributed to the acetate species at 1578 and $1458 \mathrm{~cm}^{-1}$, together with a shoulder of the enolic species at $1632 \mathrm{~cm}^{-1}$. In order to clearly observe the dynamic changes of surface species mentioned above, the spectra in the range of 1200 $2500 \mathrm{~cm}^{-1}$ were fitted on the basis of the deconvolved curves. The integrated areas of the peaks at 1458,1632 , and $2229 \mathrm{~cm}^{-1}$ in Fig. $3 \mathrm{~A}$ are displayed as a function of time on stream in Fig. 3B. Switching the feed gas to $\mathrm{NO}+\mathrm{O}_{2}$ resulted in a sharp decrease in the intensity of enolic species and acetate. A new peak of - NCO appeared at $2229 \mathrm{~cm}^{-1}$ [5,6,9,32-36], and its intensity increased with time on stream, reaching a maximum at $3 \mathrm{~min}$ and then decreasing gradually. After the flowing of $\mathrm{NO}+\mathrm{O}_{2}$ for $10 \mathrm{~min}$, the enolic species decreased slowly and the intensity of the $-\mathrm{NCO}$ peak significantly decreased. Although the intensity of the acetate species consistently decreased over the remaining time, $-\mathrm{NCO}$ showed a very low concentration, indicating that acetate is not highly reactive toward $\mathrm{NO}+\mathrm{O}_{2}$ forming $-\mathrm{NCO}$. In addition, the appearance of peaks at 1302 and $1252 \mathrm{~cm}^{-1}$ indicates the formation of surface nitrate species $[6,9,10,17]$.

The reactivity of the partial oxidation products of BA was studied in a flow of $\mathrm{NO}+\mathrm{O}_{2}$ at $573 \mathrm{~K}$, and the results are exhibited in Fig. $3 \mathrm{C}$ and $\mathrm{D}$. After exposing $\mathrm{Ag} / \mathrm{Al}_{2} \mathrm{O}_{3}$ to $\mathrm{BA}+\mathrm{O}_{2}$ for $60 \mathrm{~min}$, large amounts of enolic species $\left(1633,1412\right.$, and $\left.1340 \mathrm{~cm}^{-1}\right)$ and acetate (1578 and $1466 \mathrm{~cm}^{-1}$ ) were observed, and the former was dominant. When switching the feed gas to $\mathrm{NO}+\mathrm{O}_{2}$, the peak at $2243 \mathrm{~cm}^{-1}$ attributed to $-\mathrm{NCO}$ appeared at $2 \mathrm{~min}$. As the enolic species decreased gradually, a large amount of -NCO species was formed and remained at high concentrations even after $60 \mathrm{~min}$. After purging $\mathrm{NO}+\mathrm{O}_{2}$ for $60 \mathrm{~min}$, the intensity of acetate species did not decrease but increased slightly, indicating that the enolic
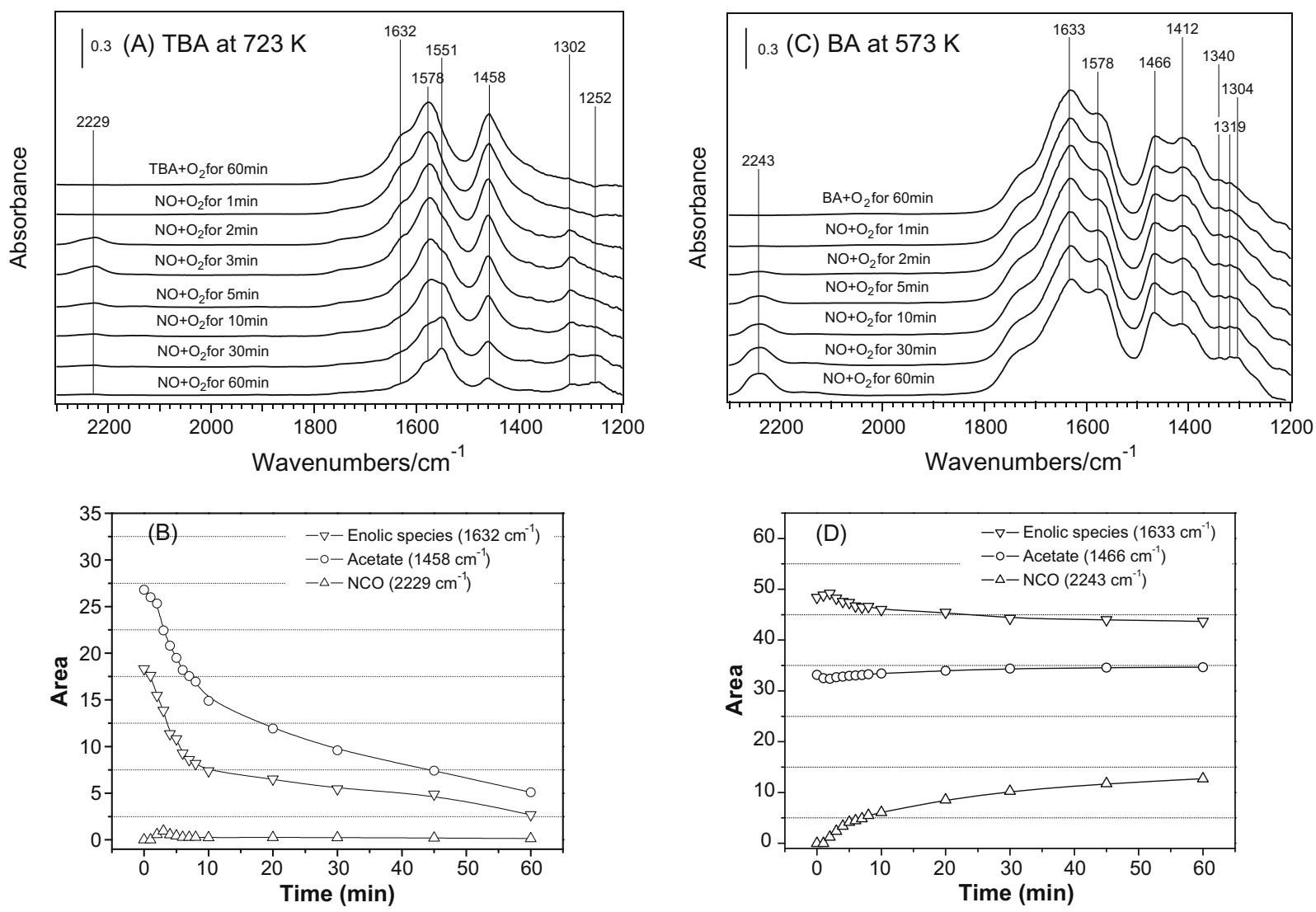

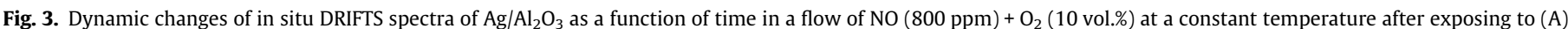

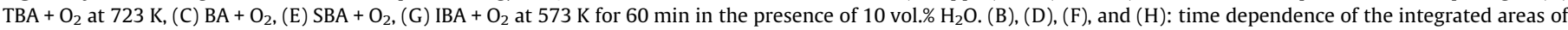
the peaks of $-\mathrm{NCO}(\Delta)$, enolic species $(\nabla)$, and acetate $(O)$ for the case of $(A),(C),(E)$, and $(G)$, respectively. 
species can further oxidize to produce acetate. These results strongly suggest the enolic species possess higher activity for reaction with $\mathrm{NO}+\mathrm{O}_{2}$ to form - NCO than that of acetate, which was in good agreement with our previous work [16,17,21].

The reactivity of the partial oxidation products of SBA and IBA was evaluated in essentially the same manner as that of $B A$, and similar changes were observed (Fig. 3E-H). In both cases, the enolic species and acetate were the main products, with the former being dominant after partial oxidation of SBA and IBA over $\mathrm{Ag} / \mathrm{Al}_{2} \mathrm{O}_{3}$. The concentration of enolic species decreased gradually, whereas the concentration of surface acetate increased a little bit over time. During this process, large amounts of $-\mathrm{NCO}$ were formed even after switching the feed gas to $\mathrm{NO}+\mathrm{O}_{2}$ for $60 \mathrm{~min}$, further demonstrating that the enolic species reacts more efficiently with $\mathrm{NO}+\mathrm{O}_{2}$ than the acetate species to obtain high concentrations of surface $-\mathrm{NCO}$.

To further investigate the reactivity of enolic species, acetate and $-\mathrm{NCO}$, the same experiments were performed at elevated temperatures of 673 and $723 \mathrm{~K}$ after SA partial oxidation. As shown in Fig. $4 \mathrm{~A}$ and $\mathrm{B}$, high concentrations of enolic species and acetate were formed after exposure of $\mathrm{Ag} / \mathrm{Al}_{2} \mathrm{O}_{3}$ to $\mathrm{BA}+\mathrm{O}_{2}$ at $673 \mathrm{~K}$. Switching the feed gas to $\mathrm{NO}+\mathrm{O}_{2}$ results in the formation of $-\mathrm{NCO}$ at the first minute, reaching the maximum at $4 \mathrm{~min}$, and then remaining at high concentrations within following $5 \mathrm{~min}$. Simultaneously, a significant decrease in the intensity of enolic species was observed while the concentration of acetate decreased slowly, further demonstrating a higher reactivity of the former than the latter. The further increase of the temperature to $723 \mathrm{~K}$ accelerated the reaction of enolic species with $\mathrm{NO}+\mathrm{O}_{2}$ to form $-\mathrm{NCO}$ and further reaction of $-\mathrm{NCO}$ with $\mathrm{NO}+\mathrm{O}_{2}$ to $\mathrm{N}_{2}$ (Fig. $4 \mathrm{C}$ and D). A sharp decrease in the surface concentration of enolic species was observed within $3 \mathrm{~min}$, and the maximum value of $-\mathrm{NCO}$ appeared at $2 \mathrm{~min}$, which was followed by a quick decrease in the concentration. This result clearly shows that the - NCO can be regarded as a key intermediate for NOx reduction by $\mathrm{BA}$, originating from the reaction between enolic species and $\mathrm{NO}+\mathrm{O}_{2}$, and possessing high reactivity toward $\mathrm{NO}+\mathrm{O}_{2}$ to form $\mathrm{N}_{2}$.

The reactivity of the partial oxidation products of SBA and IBA was evaluated in essentially the same manner as that of BA at 673 and $723 \mathrm{~K}$. In all cases, enolic species exhibits higher activity for reaction with $\mathrm{NO}+\mathrm{O}_{2}$ to produce $-\mathrm{NCO}$ than acetate; the $-\mathrm{NCO}$ species as the key intermediate for NOx reduction possesses high reactivity toward $\mathrm{NO}+\mathrm{O}_{2}$; elevated reaction temperature favors both the $-\mathrm{NCO}$ formation and its further reaction with $\mathrm{NO}+\mathrm{O}_{2}$.

\subsubsection{Steady state in situ DRIFTS study of the SCR of NOx by C4 alcohols over $\mathrm{Ag} / \mathrm{Al}_{2} \mathrm{O}_{3}$}

To further identify the mechanisms of the SCR of NOx by butyl alcohol isomers over $\mathrm{Ag} / \mathrm{Al}_{2} \mathrm{O}_{3}$, in situ DRIFTS experiments were carried out in the temperature range of $473-773 \mathrm{~K}$. The DRIFTS spectra of $\mathrm{Ag} / \mathrm{Al}_{2} \mathrm{O}_{3}$ in a flow of $\mathrm{TBA}+\mathrm{NO}+\mathrm{O}_{2}$ are shown in Fig. 5A. As mentioned earlier, the bands at 1392, 1365, 1234, and $1200 \mathrm{~cm}^{-1}$ attributable to tert-butyl $\left(-\mathrm{C}\left(\mathrm{CH}_{3}\right)_{3}\right)$ of the adsorbed TBA species were observed at temperatures below $673 \mathrm{~K}$. According to the literatures $[6,9,10,17]$, the bands at 1537 and $1302 \mathrm{~cm}^{-1}$ can be attributed to adsorbed nitrate species, and the peaks at 1576 and $1462 \mathrm{~cm}^{-1}$ are associated with the surface acetate species. An increase in the reaction temperature results in a gradual decrease in the intensity of the peaks attributed to adsorbed TBA and leads to an increase in the intensity of the acetate peaks. Simultaneously, enolic species $\left(1633 \mathrm{~cm}^{-1}\right)$ was observed at above $573 \mathrm{~K}$, and a weak peak at $2227 \mathrm{~cm}^{-1}$ attributed to -NCO was observed within the temperature range of $623-773 \mathrm{~K}$
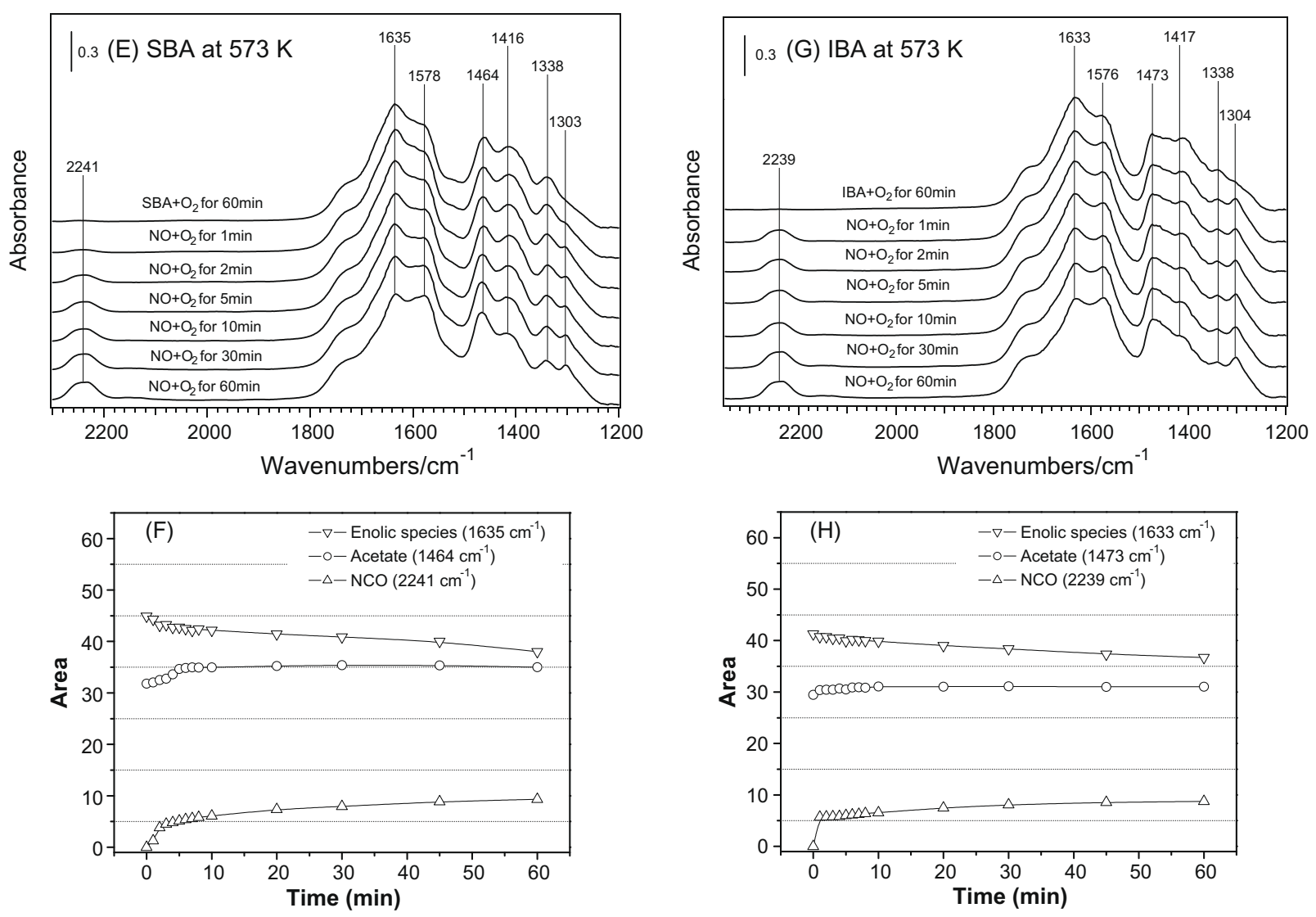

Fig. 3 (continued) 

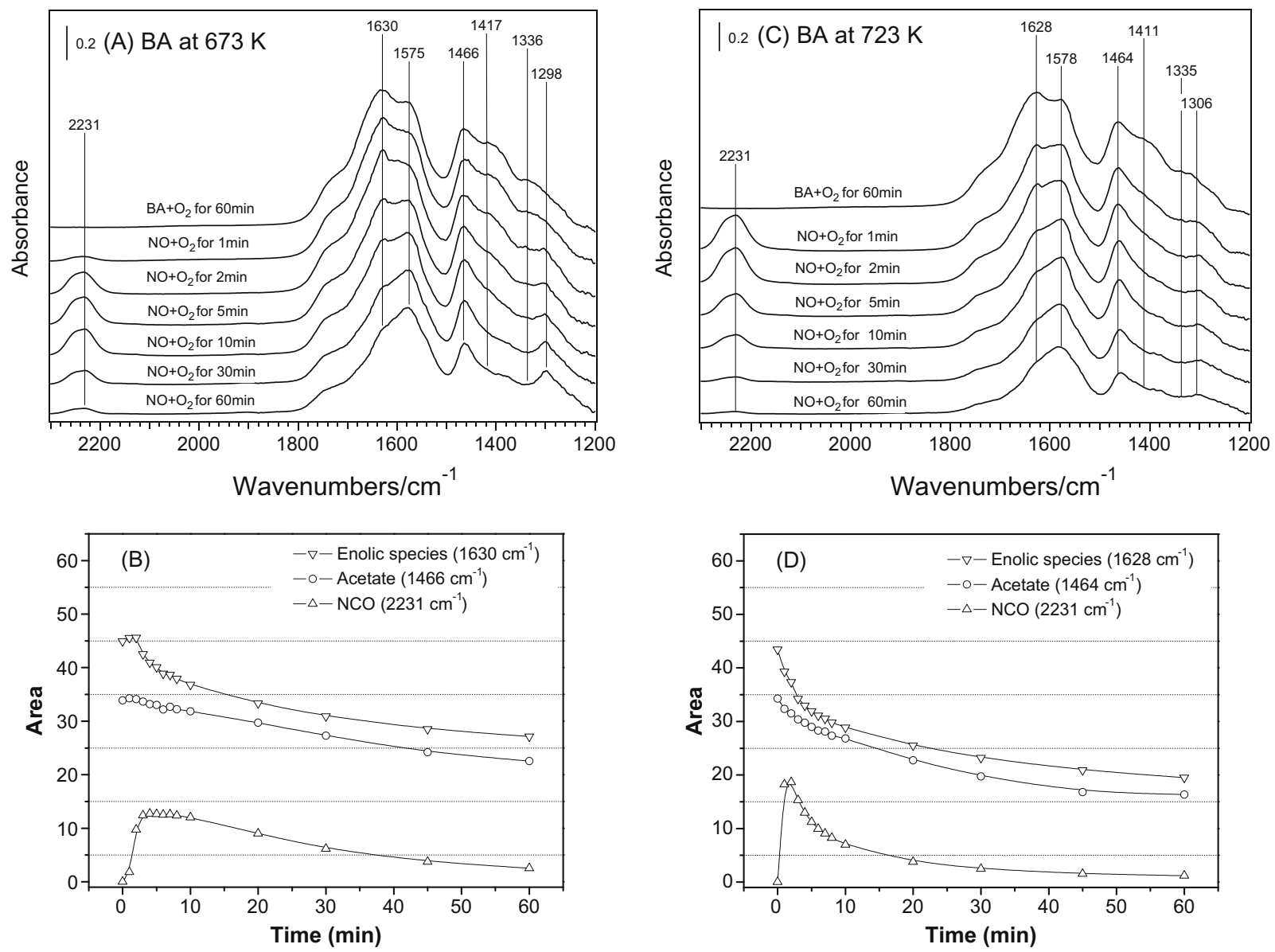

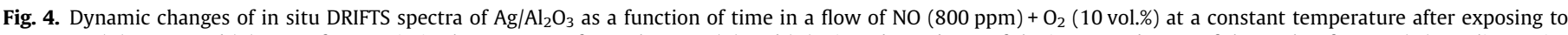

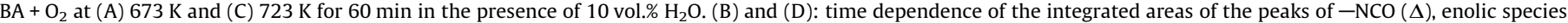
$(\nabla)$, and acetate $(O)$ for the cases of $(A)$ and $(C)$, respectively.

[5,6,9,32-36]. The peak at $1591 \mathrm{~cm}^{-1}$ can be assigned to formate species.

The in situ DRIFTS spectra over $\mathrm{Ag} / \mathrm{Al}_{2} \mathrm{O}_{3}$ in a flow of $\mathrm{BA}+-$ $\mathrm{NO}+\mathrm{O}_{2}$ are shown in Fig. 5B. Strong peaks of acetate (1570 and $\left.1466 \mathrm{~cm}^{-1}\right)$ and nitrate $\left(1585\right.$ and $1304 \mathrm{~cm}^{-1}$ ) were detected on the surface. Different from the case of TBA, a strong peak was observed at $1635 \mathrm{~cm}^{-1}$, together with shoulders at 1412 and $1338 \mathrm{~cm}^{-1}$ in the temperature region of $473-673 \mathrm{~K}$, suggesting a large amount of surface enolic species on the catalyst. As the intensity of the enolic species and nitrate decreased with increased temperature, a $-\mathrm{NCO}$ peak at $2231 \mathrm{~cm}^{-1}$ appeared at $523 \mathrm{~K}$ and remained at high intensity within the wide temperature range of 573-773 K. Similar DRIFTS spectra were observed during the NOx reduction by IBA and SBA (Fig. 5C and D), where strong enolic species (1635-1637, 1415-1417, and $1338 \mathrm{~cm}^{-1}$ ), acetate species (1572-1576, 1462-1464 $\left.\mathrm{cm}^{-1}\right)$, and nitrate species (1589-1593, 1556 , and $1302 \mathrm{~cm}^{-1}$ ) were also observed. The enolic species was also dominant within moderate temperatures, and there was a large amount of $-\mathrm{NCO}$ at temperatures above $523 \mathrm{~K}$ on the $\mathrm{Ag}$ / $\mathrm{Al}_{2} \mathrm{O}_{3}$ surface. In both cases, peaks due to methyl bending were observed at 1392 and $1379 \mathrm{~cm}^{-1}$.

\section{Discussion}

As shown in Fig. 1, BA, SBA, and IBA possess similar high efficiency for NOx reduction over $\mathrm{Ag} / \mathrm{Al}_{2} \mathrm{O}_{3}$, providing a $50 \% \mathrm{NOx}$ conversion $\left(T_{50}\right)$ at 531,520 , and $518 \mathrm{~K}$, respectively. However, NOx reduction by TBA over $\mathrm{Ag} / \mathrm{Al}_{2} \mathrm{O}_{3}$ exhibits a much lower NOx conversion in the temperature range of $473-723 \mathrm{~K}$, providing a $T_{50}$ for NOx conversion at around $694 \mathrm{~K}$, which is about $176 \mathrm{~K}$ higher than that of the $T_{50}$ by IBA.

It has been widely accepted that -NCO species is the key intermediate in the SCR of NOx by hydrocarbons or oxygenates over $\mathrm{Ag}$ / $\mathrm{Al}_{2} \mathrm{O}_{3}$. This species possesses high reactivity toward $\mathrm{NO}+\mathrm{O}_{2}$ to produce $\mathrm{N}_{2}$, and its high productivity on the catalyst surface indicates its high efficiency for NOx reduction [32-35]. Obviously, in the case of NOx reduction by BA, SBA, and IBA (Fig. 5), the formation of $-\mathrm{NCO}$ always occurred at around $520 \mathrm{~K}$, at which point the catalyst light-off for NOx reduction was achieved (Fig. 1). The high surface concentration of this species was maintained within the temperature range of $573-773 \mathrm{~K}$, which is related to its high efficiency for NOx conversion. In relation to NOx reduction by TBA, however, the -NCO species was rarely observed, even at temperatures as high as $623 \mathrm{~K}$ (Fig. 5), which results in low NOx conversion by TBA. The results clearly indicate that the different surface concentrations of $-\mathrm{NCO}$ in the cases of using TBA or the other three butyl alcohol isomers as reductants caused the differences in NOx reduction activity.

It has also been widely accepted that the partial oxidation of reductant plays a crucial role in the formation of $-\mathrm{NCO}$ during the HC-SCR of NOx $[6,9-15,30,31]$. From the in situ DRIFTS spectra of partial oxidation of BA, SBA, and IBA, the enolic species was shown to be predominant within the low temperature range of 523-673 K, together with the formation of large amounts of acetate. The enolic species showed higher activity toward $\mathrm{NO}+\mathrm{O}_{2}$ to 

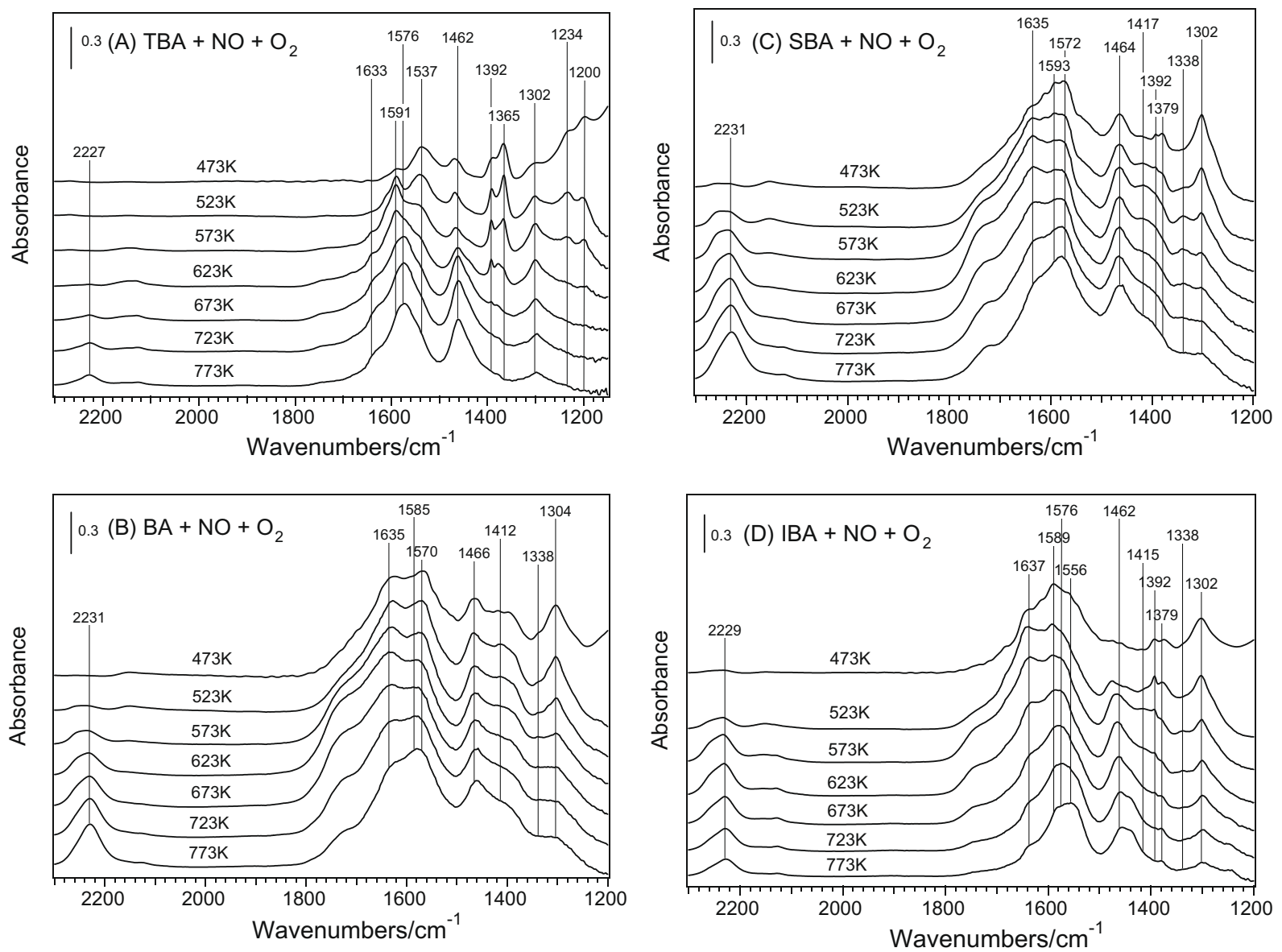

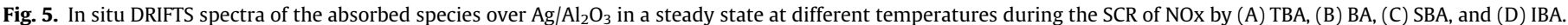
Reaction conditions: NO 800 ppm, TBA, BA, SBA, or IBA 783 ppm, $\mathrm{O}_{2} 10 \mathrm{vol} \%, \mathrm{H}_{2} \mathrm{O} 10 \mathrm{vol} . \%, \mathrm{~N}_{2}$ as balance; total flow = $300 \mathrm{ml}$ min ${ }^{-1}$.

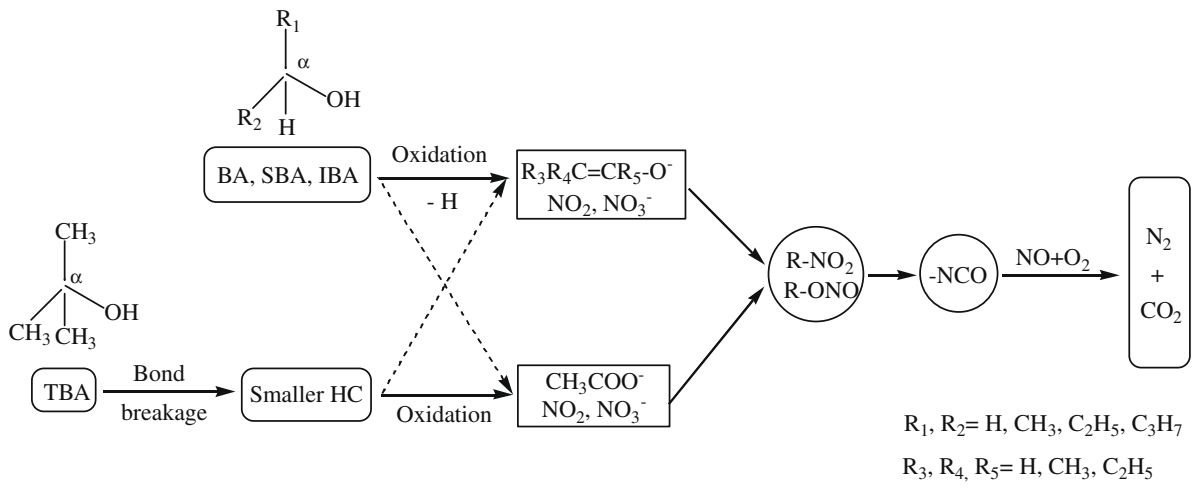

Scheme 2. The proposed mechanism of the SCR of NOx by butyl alcohol isomers over $\mathrm{Ag} / \mathrm{Al}_{2} \mathrm{O}_{3}$.

form - NCO than acetate and resulted in a high surface concentration of $-\mathrm{NCO}$ species (Figs. 3 and 4). This relates to the high efficiency of NOx reduction by these three alcohols. In relation to TBA, however, the partial oxidation at temperatures below $573 \mathrm{~K}$ is difficult. Consequently, it is reasonable that TBA shows lower NOx conversion at this temperature range. At temperatures above $573 \mathrm{~K}$, acetate, not enolic species, became the main surface species. In this case, the acetate plays a key role in - NCO formation and results in a lower concentration of $-\mathrm{NCO}$ during the NOx reduction by TBA over $\mathrm{Ag} / \mathrm{Al}_{2} \mathrm{O}_{3}$.

After exposing the catalyst to $\mathrm{BA}+\mathrm{O}_{2}$ for $60 \mathrm{~min}$ at $573 \mathrm{~K}$ (Fig. 3C and D), the surface was covered by high concentration of enolic species and acetate. With this in mind, the monotonic increase in integral intensity of $-\mathrm{NCO}$ during flowing $\mathrm{NO}+\mathrm{O}_{2}$ at $573 \mathrm{~K}$ possibly caused by the insufficiency of active sites available for NO oxidation and nitrate formation. Elevated the reaction temperatures decreased the surface concentration of enolic species, providing more active sites for NO oxidation and nitrate formation, hence accelerating the consumption of $-\mathrm{NCO}$ by $\mathrm{NO}+\mathrm{O}_{2}$ to produce $\mathrm{N}_{2}$, with the results shown in Fig. $4 \mathrm{~B}$ and $\mathrm{D}$.

As reported by Sachtler and coworkers [37,38], there is another route leading to $\mathrm{N}_{2}$ formation via isocyanate hydrolysis during the HC-SCR of NOx. In this case, $-\mathrm{NCO}$ is to be hydrolyzed by water to produce more reactive ammonia to form $\mathrm{N}_{2}$ over zeolite-based cat- 
alysts. As suggested by Haneda et al. [39], -NCO was hydrolyzed to the surface $-\mathrm{NH}$ complexes by the reaction with traces of water during NOx reduction by propene over $\mathrm{Ga}_{2} \mathrm{O}_{3}-\mathrm{Al}_{2} \mathrm{O}_{3}$, giving the $\mathrm{N}-\mathrm{H}$ stretching vibration at around $3400 \mathrm{~cm}^{-1}$. In our case, however, the $\mathrm{N}-\mathrm{H}$ stretching vibration was hardly observed, indicating that the pathway involved in the hydrolyzation of $-\mathrm{NCO}$ could be neglectable in the SCR of NOx by $\mathrm{C} 4$ alcohols over $\mathrm{Ag} / \mathrm{Al}_{2} \mathrm{O}_{3}$.

It is obvious now that different structures of butyl alcohol isomers result in different surface concentrations of the partial oxidation products and different concentrations of $-\mathrm{NCO}$, which subsequently contributes to the different performances of $\mathrm{Ag}$ / $\mathrm{Al}_{2} \mathrm{O}_{3}$ for NOx reduction by these alcohols.

In essence, the partial oxidation of alcohols to aldehydes and/or ketones can be regarded as a dehydrogenation reaction, suggesting that the structural feature of $\mathrm{H}-\mathrm{C}-\mathrm{O}-\mathrm{H}$ is required for this process. In other words, the $\mathrm{OH}$ group must be attached to a carbon atom that is bonded to at least one $\alpha-\mathrm{H}$. It is clear that tertiary alcohols such as TBA cannot undergo oxidation to form aldehydes and/ or ketones because of the absence of $\alpha-\mathrm{H}$. Since enols in the gas phase and adsorbed enolic species are the tautomers of aldehydes and ketones, the presence of $\alpha-\mathrm{H}$ is also a prerequisite for their formation during the partial oxidation of alcohols over $\mathrm{Ag} / \mathrm{Al}_{2} \mathrm{O}_{3}$. As a result, large amounts of enolic species were formed during the partial oxidation of IB, SBA, and IBA over $\mathrm{Ag} / \mathrm{Al}_{2} \mathrm{O}_{3}$ at low temperatures. In addition, these three alcohols and/or enolic species can be broken up into smaller hydrocarbon molecules, which are subsequently oxidized to acetate, particularly in high temperatures. In relation to TBA, the elimination of $\alpha-\mathrm{H}$ is impossible and thus the partial oxidation follows a different pathway. Its oxidation process starts with the breakup of the carbon chain into smaller molecules, which requires extra energy and therefore tends to favor high temperatures. Results from this study show that at high temperatures, oxidation of the smaller molecules to acetate and formate occurred, together with the formation of trace amounts of surface enolic species.

On the basis of the above analyses, together with the results of previous studies [5,6,10-20], the mechanisms of the SCR of NOx by C4 alcohols with different structures were proposed in Scheme 2. The reaction starts with the formation of both adsorbed nitrates via $\mathrm{NO}$ oxidation by $\mathrm{O}_{2}$ and enolic species and acetate via the partial oxidation of alcohols over $\mathrm{Ag} / \mathrm{Al}_{2} \mathrm{O}_{3}$. The reaction between the two kinds of adsorbed species then leads to the formation of -NCO, possibly via organo-nitrogen compounds (such as $\mathrm{R}-\mathrm{ONO}$ and $\mathrm{R}-\mathrm{NO}_{2}$ ). Subsequently, $-\mathrm{NCO}$ reacts with $\mathrm{NO}+\mathrm{O}_{2}$ and/or nitrates to yield $\mathrm{N}_{2}$. The enolic species and surface acetate, as the intermediates derived from the partial oxidation of reductants, show different activity to form -NCO. TBA follows the pathway involved in the breakup of the carbon chain and then oxidization to acetate and formate. The relatively low activity of acetate and formate toward $\mathrm{NO}+\mathrm{O}_{2}$ results in a low concentration of $-\mathrm{NCO}$ $[17,21,22]$, finally relating to a low NOx conversion by TBA. In regard to NOx reduction by primary and secondary butyl alcohols (BA, SBA and IBA), however, the presence of $\alpha$-H opens an avenue to the formation of enolic species. Its high surface concentration and high reactivity toward $\mathrm{NO}+\mathrm{O}_{2}$ results in high concentrations of $-\mathrm{NCO}$, which determines the high efficiency for NOx reduction by these three alcohols over $\mathrm{Ag} / \mathrm{Al}_{2} \mathrm{O}_{3}$.

\section{Conclusions}

Alcohol structure has a significant influence on the activity of $\mathrm{Ag} / \mathrm{Al}_{2} \mathrm{O}_{3}$ for $\mathrm{NOx}$ reduction by butyl alcohol isomers, including
TBA, BA, SBA, and IBA. Similarly high activity for NOx reduction over $\mathrm{Ag} / \mathrm{Al}_{2} \mathrm{O}_{3}$ was shown for $\mathrm{BA}$, IBA, and SBA, while TBA gave a much lower NOx conversion in the temperature range of 473$773 \mathrm{~K}$. BA, IBA, and SBA containing $\alpha-\mathrm{H}$ are favorable for the partial oxidation to form enolic species, while the $\alpha-\mathrm{H}$ participated reaction pathway is impossible for TBA due to the absence of $\alpha-\mathrm{H}$. The dominant pathway of TBA oxidation involves the breakup of alcohol molecules, leading to an oxidation to acetate and formate. The lower reactivity of the acetate and formate toward NOx resulted in a low concentration of - NCO species, and consequently low NOx conversion. Our study provides an intrinsic criterion for the selection of alcohols as reductants with high efficiency for NOx removal.

\section{Acknowledgments}

This work was financially supported by the National Natural Science Foundation of China (20773158, 50921064) and the Knowledge Innovation Program of the Chinese Academy of Sciences (KZCX1-YW-06-04).

\section{References}

[1] M. Iwamoto, H. Yahiro, Catal. Today 22 (1994) 5.

[2] M. Shelef, Chem. Rev. 95 (1995) 209.

[3] T. Miyadera, Appl. Catal. B 2 (1993) 199.

[4] K.A. Bethke, H.H. Kung, J. Catal. 172 (1997) 93.

[5] S. Sumiya, H. He, A. Abe, N. Takezawa, K. Yoshida, J. Chem. Soc., Faraday Trans. 94 (1998) 2217.

[6] S. Kameoka, Y. Ukisu, T. Miyadera, Phys. Chem. Chem. Phys. 2 (2000) 367.

[7] K. Shimizu, A. Satsuma, T. Hattori, Appl. Catal. B 25 (2000) 239.

[8] A. Martínez-Arisa, M. Fernández-García, A. Iglesias-Juez, J.A. Anderson, J.C. Conesa, J. Soria, Appl. Catal. B 28 (2000) 29.

[9] R. Burch, J.P. Breen, F.C. Meunier, Appl. Catal. B 39 (2002) 283.

[10] Y.H. Yeom, M. Li, M.H.W. Sachtler, E. Weitz, J. Catal. 238 (2006) 100.

[11] J.H. Lee, S.J. Schmieg, S.H. Oh, Appl. Catal. A 342 (2008) 78.

[12] Y.F. Tham, J.-Y. Chen, R.W. Dibble, Proc. Combust. Inst. 32 (2009) 2827.

[13] T. Chafik, S. Kameoka, Y. Ukisu, T. Miyadera, J. Mol. Catal. A 136 (1998) 203.

[14] Y.H. Yeom, M. Li, M.H.W. Sachtler, E. Weitz, J. Catal. 246 (2007) 413.

[15] R. da Silva, R. Cataluña, A. Martínez-Arias, Catal. Today 143 (2009) 211.

[16] Y. Yu, H. He, Q. Feng, J. Phys. Chem. B 107 (2003) 13090.

[17] Y. Yu, H. He, Q. Feng, H. Gao, X. Yang, Appl. Catal. B 49 (2004) 159.

[18] Y. Yu, H. Gao, H. He, Catal. Today 93-95 (2004) 805.

[19] H. He, Y. Yu, Catal. Today 100 (2005) 37.

[20] H. He, X. Zhang, Q. Wu, C. Zhang, Y. Yu, Catal. Surv. Asia 12 (2008) 38.

[21] Q. Wu, H. He, Y. Yu, Appl. Catal. B 61 (2005) 107.

[22] Q. Wu, Y. Yu, H. He, Chin. J. Catal. 27 (2006) 993.

[23] A. Takahashi, M. Haneda, T. Fujitani, H. Hamada, J. Mol. Catal. A 261 (2007) 6.

[24] Q. Yu, X. Wang, N. Xing, H. Yang, S. Zhang, J. Catal. 245 (2007) 124.

[25] C.A. Taatjes, N. Hansen, A. McIlroy, J.A. Miller, J.P. Senosiain, S.J. Klippenstein, F. Qi, L. Sheng, Y. Zhang, T.A. Cool, J. Wang, P.R. Westmoreland, M.E. Law, T. Kasper, K. Kohse-Höinghaus, Science 308 (2005) 1887.

[26] Y. Li, X. Zhang, H. He, Y. Yu, T. Yuan, Z. Tian, J. Wang, Y. Li, Appl. Catal. B 89 (2009) 659.

[27] J. Korppi-Tommola, Spectrochim. Acta 34A (1978) 1077.

[28] J. Raskó, T. Kecskés, J. Kiss, J. Catal. 224 (2004) 261.

[29] C. Zhang, H. He, K. Tanaka, Appl. Catal. B 65 (2006) 37.

[30] K. Shimizu, H. Kawabata, A. Satuma, T. Hattori, Appl. Catal. B 19 (1998) L87.

[31] K. Shimizu, H. Kawabata, A. Satsuma, T. Hattori, J. Phys. Chem. B 103 (1999) 5240.

[32] S. Kameoka, T. Chafik, Y. Ukisu, T. Miyadera, Catal. Lett. 51 (1998) 11

[33] S. Kameoka, T. Chafik, Y. Ukisu, T. Miyadera, Catal. Lett. 55 (1998) 211.

[34] N. Bion, J. Saussey, M. Haneda, M. Daturi, J. Catal. 217 (2003) 47.

[35] S. Tamm, H.H. Ingelsten, A.E.C. Palmqvist, J. Catal. 255 (2008) 304.

[36] F. Thibault-Starzyk, E. Seguin, S. Thomas, M. Daturi, H. Arnolds, D.A. King, Science 324 (2009) 1048.

[37] H.-Y. Chen, Q. Sun, B. Wen, Y.-H. Yeom, E. Weitz, W.M.H. Sachtler, Catal. Today 96 (2004) 1.

[38] B. Wen, Y.-H. Yeom, E. Weitz, W.M.H. Sachtler, Appl. Catal. B 48 (2004) 125.

[39] M. Haneda, N. Bion, M. Daturi, J. Saussey, J.-C. Lavalley, D. Duprez, H. Hamada, J. Catal. 206 (2002) 114. 